\title{
Sexual dimorphism of drumming muscles in European hake (Merluccius merluccius)
}

\author{
Anne-Laure Groison • Olav S. Kjesbu • \\ Marc Suquet
}

Received: 9 December 2009 / Accepted: 11 November 2010/Published online: 1 December 2010

(C) The Author(s) 2010. This article is published with open access at Springerlink.com

\begin{abstract}
Dissections of mature and non-mature European hake males and females $(N=142)$ collected in waters off the western coast of Norway and in the Bay of Biscay (France) in 2004-2006 demonstrate for the first time that this gadoid species contains drumming muscles. There were differences in drumming muscles weight with body length, sex and maturity stage. This study shows that the difference between females and males is primarily manifested during the spawning season, seen both in the French and Norwegian samples. For the mature females the drumming muscles dry weight increases only slightly, if at all, with increase in total length. For mature males there is a corresponding rapid increase. There does not seem to be any consistent difference between the average dry weight of the drumming muscles in immature male and immature and mature female hake of the same length, tested on the Norwegian samples.
\end{abstract}

A.-L. Groison $(\square)$

Department of Biology, University of Bergen,

P.O. Box 7803, Thormøhlensgate 55,

5020 Bergen, Norway

e-mail: Anne-Laure.Groison@imr.no

A.-L. Groison · O. S. Kjesbu

Institute of Marine Research,

Nordnesgaten 50, P.O. Box 1870, Nordnes 5817 Bergen,

Norway

M. Suquet

IFREMER, PFOM / ARN,

29840 Argenton, France
Our results suggest that male hake, like the males of other gadoids studied, may produce sounds in the context of spawning.

Keywords Drumming muscles $\cdot$ Merluccius merluccius $\cdot$ Sexual dimorphism $\cdot$ Sound production . Spawning

\section{Introduction}

More than 800 fishes from 109 families are known to produce sounds, though this is likely to be an underestimate (Rountree et al. 2003). It is evident that most of these sounds are deliberate rather than incidental. These sounds have a role in communication, i.e., are used as exchange of information between individual fish as part of their social behaviour (Hawkins and Myrberg 1983). Thus, fish produce sounds in a variety of contexts. Sounds are produced by some species when disturbed or when approached by a predator. Likewise, sounds are also produced by fish which are competing with one another for food or space (Ladich and Myrberg 2006). In many sound-producing fish males produce sounds during courtship of the female to advertise their nest sites, to attract the female, and promote courtship and spawning (Myrberg and Lugli 2006). The gas-filled swimbladder is a characteristic feature of the viscera of teleost fish. It contributes to the ability of a fish to control its buoyancy, and thus to stay at the current 
water depth without having to waste energy in depthcompensating swimming activity. Another function of the gas bladder is the use as a resonating chamber to produce or receive sound and in some species is equipped with drumming muscles (DM) for sound production. Sounds are produced by contracting DM associated with the swimbladder and thereby vibrating the swimbladder wall (Jones and Marshall 1953; Brawn 1961).

It is known that one particular family, the Gadidae, includes a number of vocal species (Hawkins and Rasmussen 1978), including haddock (Melanogrammus aeglefinus) (Hawkins and Chapman 1966), lythe (Pollachius virens) (Hawkins and Rasmussen 1978), tadpole fish (Raniceps raninus) (Hawkins and Rasmussen 1978) and Atlantic cod (Gadus morhua) (Brawn 1961).

In their work on cod Nordeide et al. (2008) found that the DM mass was similar in both sexes a couple of months prior to spawning but became sexually dimorphic at the onset of spawning and continued being sexually dimorphic (bigger in males) for several months after the termination of spawning.

To date, no studies have investigated whether European hake (Merluccius merluccius) possess drumming muscles. This is somewhat surprising in view of the importance of this species, and the fact that the presence of drumming muscles have been reported in other gadoid species.

European hake is a semi-demersal, multiple batch spawner found in waters from Mauritania to Norway. It is believed that hake spawning and reproduction occur at depth ranging 100-200 m (Alvarez et al. 2001; Olivar et al. 2003). The peak spawning time of hake is in March in waters south of the Bay of Biscay (France), and occurs progressively later at higher latitudes (Casey and Pereiro 1995).

In the present study we sampled wild hake males and females from French (Bay of Biscay) and Norwegian waters at different times of the year to search for the presence of drumming muscles and, if so, to quantify variation among individuals in drumming muscles size. Specifically, our objectives were to $(a)$ record differences in drumming muscle appearance and mass in relation to sex, spawning status, and body size; and (b) compare hake drumming muscles with what has been observed in other gadoids.

\section{Material and methods}

Fish collection

A total of 142 wild European hake were sampled offshore Western Norway $(\mathrm{Nw})\left(61^{\circ} 34^{\prime} \mathrm{N}, 5^{\circ} 56^{\prime} \mathrm{W}\right)$ and in the Bay of Biscay, France (Fr) $\left(47^{\circ} 44^{\prime} \mathrm{N}, 4^{\circ} 2^{\prime} \mathrm{W}\right)$ (Table 1). Each fishing trip typically lasted 1-3 days. Non-mature fish were captured by trawl in Nw waters while mature fish were captured at both locations by gillnets set overnight at depths of between 30-180 m over sandy sea bottom. Recently dead fish (few hours) were retrieved from the gillnets.

Fish dissection

The fish were transported to laboratory to be dissected within 12-32 h of sampling, and all showed muscles attached to the swimbladder on both sides. For each individual examined we recorded total body length ( $N=$ 140; TL to the nearest $0.1 \mathrm{~cm}$ was measured for all fish except for one individual with damaged tail), total (i.e., ungutted) body mass ( $N=138$; TW) and gonad mass $(N=61)$ (to the nearest $0.1 \mathrm{~g}$ consulting only gonads which were not smashed or deteriorated by stripping). Sex and maturity stage (immature, ripening, ripe/ spawning, and spent) were recorded. Only two groups of individuals were considered: "spawning" (sp.) for ripening or ripe/spawning individuals $(N=69)$ and "non-spawning" (n. sp.) for immature or spent individuals $(N=73)$. The pair of DM was easily separated from the surrounding tissue using forceps. After excision, DM were dried at $65^{\circ} \mathrm{C}$ for 3 days to obtain dry weight to the nearest $0.001 \mathrm{mg}(N=141)$. The following fish characteristics were calculated: condition factor $\left(\mathrm{K}=\left[\right.\right.$ Total weight $\left./(\mathrm{TL})^{3}\right] \times 100$, $N=138)$; gonadosomatic index (GSI $=[$ Gonad weight $/ \mathrm{TW}] \times 100$ in $\%, N=61)$, and hepatosomatic index $(\mathrm{HSI}=[$ Liver weight $/ \mathrm{TW}] \times 100 \mathrm{in} \%, N=71)$.

Statistical analysis

Data were presented as means \pm SD. Measured and calculated characteristics of the dissected fish were combined (Table 2). Statistical analyses were performed using the software SigmaStat 3.1. Statistical significant difference between two groups were tested at the probability level 0.05 using Student $t$-test (when data were distributed normally and variances were not 
Table 1 Summary of spawning and nonspawning European hake captured in the Bay of Biscay (France, Fr) and in waters western Norway $(\mathrm{Nw})$ at different dates in 2004-2005-2006

\begin{tabular}{|c|c|c|c|c|c|}
\hline \multirow[b]{2}{*}{ Date } & \multirow[b]{2}{*}{ Origin } & \multicolumn{2}{|c|}{ Spawning fish, $N=$} & \multicolumn{2}{|c|}{ Non spawning fish, $N=$} \\
\hline & & Females & Males & Females & Males \\
\hline 20 March 2006 & $\mathrm{Fr}$ & 9 & 10 & 0 & 0 \\
\hline 04 April 2006 & $\mathrm{Fr}$ & 6 & 14 & 0 & 0 \\
\hline 17 August 2005 & $\mathrm{Nw}$ & 7 & 6 & 0 & 1 \\
\hline 22 August 2006 & $\mathrm{Nw}$ & 1 & 1 & 0 & 0 \\
\hline 23 August 2004 & $\mathrm{Nw}$ & 0 & 0 & 9 & 6 \\
\hline 23 August 2005 & $\mathrm{Nw}$ & 0 & 1 & 0 & 1 \\
\hline 01 September 2005 & $\mathrm{Nw}$ & 6 & 5 & 1 & 0 \\
\hline 12 September 2006 & $\mathrm{Nw}$ & 1 & 2 & 0 & 0 \\
\hline 27 September 2004 & $\mathrm{Nw}$ & 0 & 0 & 10 & 13 \\
\hline 12 October 2004 & $\mathrm{Nw}$ & 0 & 0 & 14 & 13 \\
\hline 13 October 2006 & $\mathrm{Nw}$ & 0 & 0 & 2 & 2 \\
\hline 30 November 2004 & $\mathrm{Nw}$ & 0 & 0 & 0 & 1 \\
\hline Total & & $15 \mathrm{Nw}+15 \mathrm{Fr}$ & $15 \mathrm{Nw}+24 \mathrm{Fr}$ & $36 \mathrm{Nw}$ & $37 \mathrm{Nw}$ \\
\hline
\end{tabular}

significantly different) or Mann-Whitney Rank Sum test (if one of these two previous conditions, or both, were invalidated). As the fish dissection resulted in an uneven number of left $(N=141)$ and right DM $(N=$ $120)$ a pilot analysis was run to test for any differences in dry weight between them, which turned out not to be the case (Mann-Whitney rank sum test, $P>0.05$ ). Therefore, in the following analysis dry weight of the left DM were used and named DM. ANCOVA with total length as covariate was used to test for differences in drumming muscle mass in relation to sex and spawning status (i.e. "spawning" (sp.) for ripening or ripe/spawning individuals and "non-spawning" (n. sp.) for immature or spent individuals). Relationships between DM dry weight and characteristics of $\mathrm{sp}$. and n. sp. individuals (TL, TW, K, GSI and HSI) were investigated with Pearson correlations. Correlations were investigated separately for Norwegian and French fish and for males and females.

\section{Results}

Fish and observations of drumming muscles

Nw-spawning individuals for both sexes showed significant higher GSIs compared to Fr-spawning individuals (Table 2).

The present study showed the presence of DM in hake: a pair of muscular structures is located at the anterior end of the swimbladder, close to its ventral wall (Nw female: Fig. 1a; Nw male: Fig. 1b). Note that the DM are rounded at the posterior end but slightly pointed anteriorly and considerably larger in
Table 2 Mean \pm SD values of fish characteristics measured on spawning and non-spawning hake for male and female (Fem.) captured in the Bay of Biscay (France, Fr) and western Norway waters (Nw): total length (TL), total weight (TW), dry weight of the left drumming muscles (DM), gonadosomatic index (GSI), condition factor (K) and hepatosomatic index (HSI)

\begin{tabular}{llllllllll}
\hline Maturation state & Origin & Sex & $N$ & TL $(\mathrm{cm})$ & TW $(\mathrm{g})$ & DM (mg) & GSI (\%) & K & HSI (\%) \\
\hline Non-spawning & \multirow{2}{*}{ Nw } & Fem. & 37 & $28.7 \pm 15.2$ & $327.2 \pm 815.1$ & $3.12 \pm 5.41$ & $1.56 \pm 2.89$ & $0.57 \pm 0.06$ & $2.60 \pm 1.58$ \\
& & Male & 37 & $27.1 \pm 11.6$ & $143.7 \pm 166.1$ & $10.15 \pm 23.74$ & $0.17 \pm 0.05$ & $0.56 \pm 0.05$ & $1.58 \pm 0.03$ \\
Spawning & \multirow{2}{*}{ Nw } & Fem. & 15 & $75.5 \pm 7.5$ & $3085.3 \pm 1273.1$ & $23.27 \pm 8.96$ & $9.38 \pm 4.25$ & $0.69 \pm 0.08$ & $4.98 \pm 5.20$ \\
& \multirow{2}{*}{ Fr } & Male & 15 & $69.1 \pm 8.7$ & $2477.1 \pm 852.2$ & $225.7 \pm 123.6$ & $4.12 \pm 2.78$ & $0.69 \pm 0.06$ & $2.71 \pm 1.06$ \\
& & Fem. & 15 & $64.7 \pm 13.0$ & $2120.1 \pm 1423.1$ & $18.38 \pm 9.41$ & $5.10 \pm 2.03$ & $0.71 \pm 0.06$ & $3.33 \pm 0.83$ \\
& & Male & 24 & $45.7 \pm 13.4$ & $784.3 \pm 690.3$ & $98.75 \pm 78.29$ & $1.44 \pm 0.88$ & $0.63 \pm 0.07$ & $2.20 \pm 1.07$ \\
\hline
\end{tabular}


Fig. 1 Dissection of spawning hake caught on 18

August 2005 in waters off Western Norway. Total length (TL), total weight (TW) and the dry weight of the left drumming muscles (DM) are indicated. (a) Dissection of a spawning female. $\mathrm{TL}=83 \mathrm{~cm}, \mathrm{TW}=4$ $270 \mathrm{~g}$ and dry weight of left drumming muscles $=22 \mathrm{mg}$. (b) Dissection of a spawning male. $\mathrm{TL}=80 \mathrm{~cm}, \mathrm{TW}=3$ $440 \mathrm{~g}$ and dry weight of left drumming muscles $=266 \mathrm{mg}$
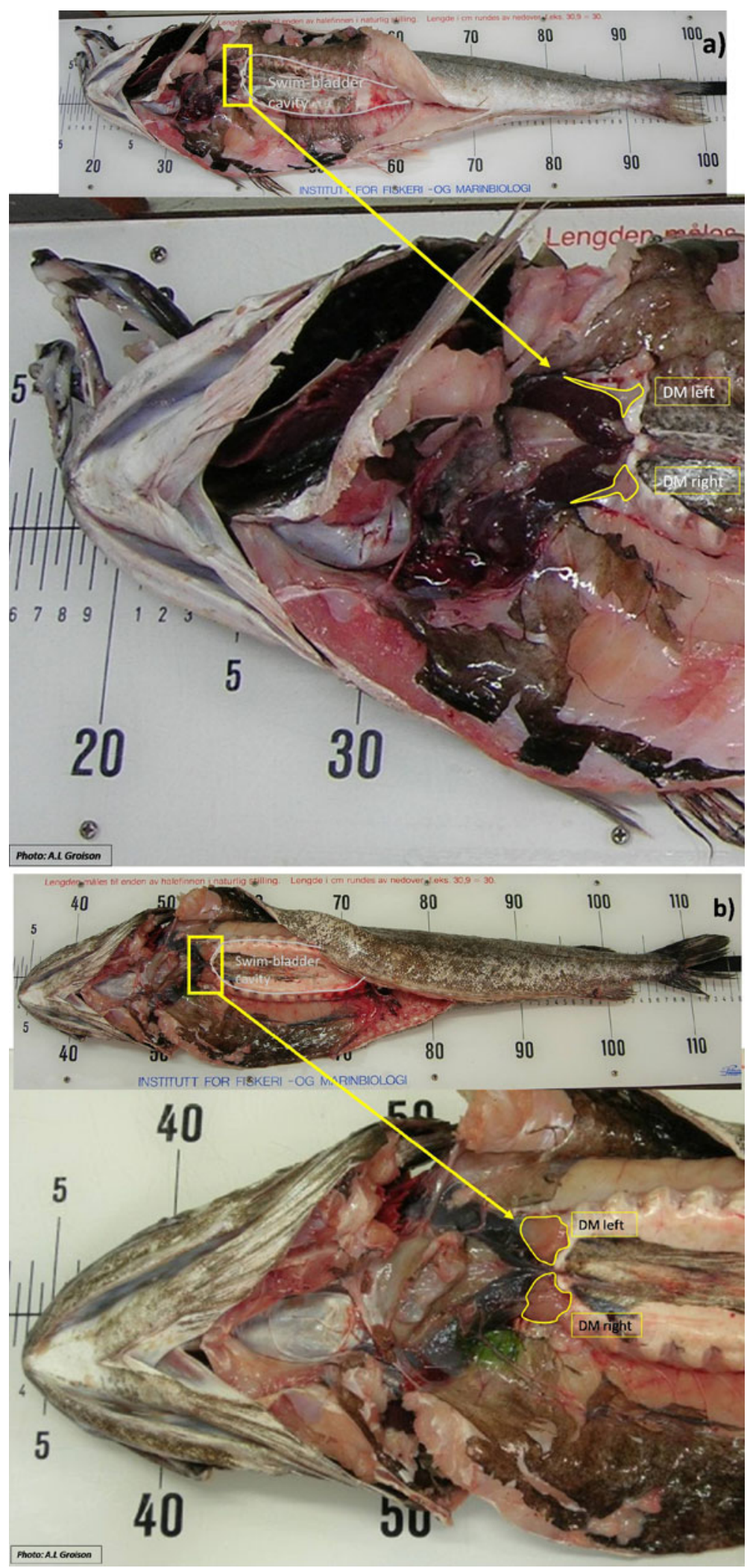
Fig. 2 Variation in left drumming muscle dry weight (DM in $\mathrm{mg}$ ) in relation to total length (TL in $\mathrm{cm}$ ) of European hake for females (circles) and males (triangles), split into non-spawning (open symbol) and spawning individuals (filled symbol) for Norwegian (a) and (b), and for French samples (c) and (d)

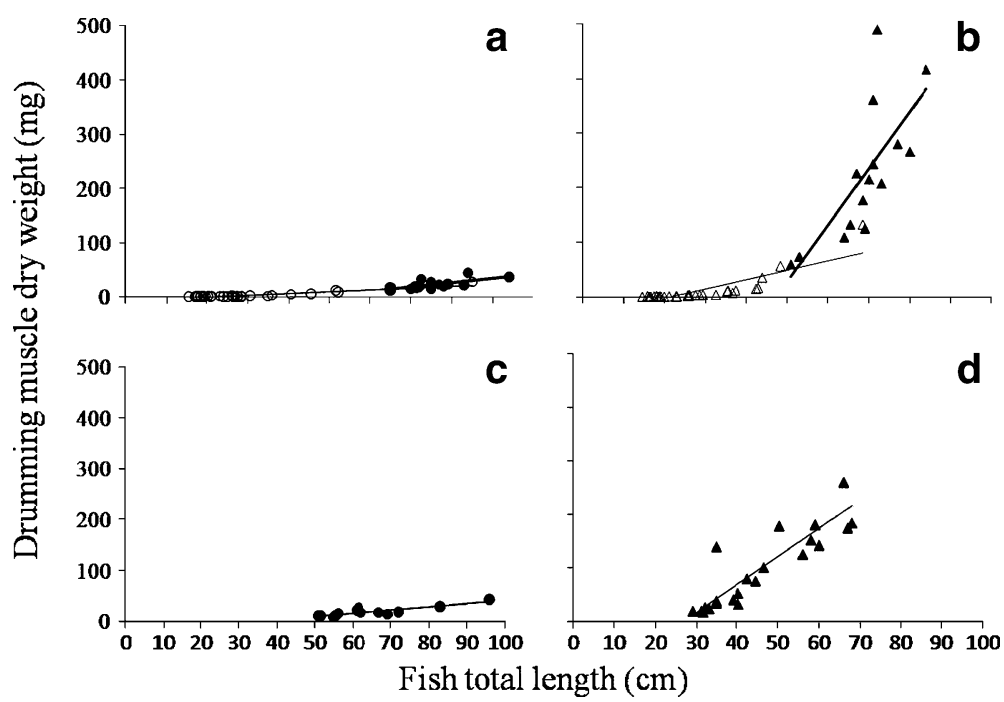

the male than in the female of similar length $(\approx 80 \mathrm{~cm})$, i.e., in the present example the male DM dry weight was 12 times larger than in the female. The DM of the female sits as a flat structure on the swimbladder wall whereas for the mature male it appears much thicker. For mature specimens there was noticed a difference in the colour of the male and female DM as viewed in situ: the DM of the mature male for all size classes tends to be reddish fleshcoloured, while light pinkish for females.

Relation of drumming muscles dry weight to length, sex and maturity stage

There were examples of significant correlations between DM dry weight and fish total length (Fig. 2; Table 3). However, for spawning females the DM dry weight increased only slightly with length while for spawning males there was a rapid increase at larger lengths. For the same length, $\mathrm{Nw}$ spawning males had a significantly heavier DM compared to $\mathrm{Nw}$ non-spawning males (Fig. 2b) $(P<0.001)$
(ANCOVA). The same result appeared when compared to Nw non-spawning females (Fig. $2 \mathrm{a}+\mathrm{b})(P<$ $0.001)$ and also very much in relation to $\mathrm{Nw}$ spawning females (Fig. $2 \mathrm{a}+\mathrm{b})(P<0.01)$. The ANCOVA also showed that Fr spawning males had significantly heavier DM compared to Fr spawning females (Fig. 2c+d) $(P<0.001)$.

\section{Discussion}

Observations of the drumming muscles of male and female hake

The present study showed the presence of a sexually dimorphic muscle in hake males and females. The main evidence that this fish produce sounds is provided by the presence of a pair of muscles, one on either side of the swimbladder, similar to those found in known vocalists (as e.g., haddock, cod, lythe (Pollachius pollachius), and tadpole-fish (Raniceps raninus)) (Sørensen 1884; Hagman 1921; Jones and
Table 3 Regression equations describing left drumming muscle dry weight $(y)$ as a function of total length $(x)$ for female and male hake from Western Norway $(\mathrm{Nw})$ and France (Fr) (Bay of Biscay) in non-spawning and spawning conditions

\begin{tabular}{llllccc}
\hline Maturation state & Origin & Sex & Regression equations & Sample size & $r^{2}$ & $P$-values \\
\hline Non-spawning & \multirow{2}{*}{ Nw } & Fem. & $y=0.333 x-6.45$ & 37 & 0.937 & $P<0.001$ \\
& & Male & $y=1.721 x-36.96$ & 36 & 0.835 & $P<0.001$ \\
\multirow{2}{*}{ Spawning } & \multirow{2}{*}{ Nw } & Fem. & $y=0.833 x-39.65$ & 15 & 0.701 & $P<0.01$ \\
& \multirow{2}{*}{ Fr } & Male & $y=10.402 x-492.76$ & 15 & 0.734 & $P<0.01$ \\
& Fem. & $y=0.623 x-21.87$ & 13 & 0.864 & $P<0.001$ \\
& Male & $y=5.264 x-141.55$ & 24 & 0.904 & $P<0.001$ \\
\hline
\end{tabular}


Marshall 1953; Templeman and Hodder 1958). In cod, Delaroche (1809) and Sørensen (1884) describe the weak, flattened muscles which pass from the sides of the swimbladder at its anterior end to the ribs of the anterior vertebrae. Jones and Marshall (1953) label these external swimbladder muscles of the cod as drumming muscles (DM). In the European haddock, special groups of muscles attached to the ventral wall of the swimbladder defined as well as drumming muscles were described by Templeman and Hodder (1958). These anatomical similarities found between the DM described in cod or in haddock in comparison with the muscles presently described in hake provide more circumstantial evidence for the idea that hake produce sounds. Sound production is caused by rapid contraction and relaxation of the DM attached to the swimbladder, as mentioned earlier (Templeman and Hodder 1958; Brawn 1961; Hawkins and Rasmussen 1978; Hawkins and Amorim 2000).

Relation of drumming muscles dry weight to length, sex and maturity stage

Presently collected Norwegian $(\mathrm{Nw})$ spawning individuals showed significant higher GSI compare to the French (Fr) spawning individuals, respectively for females and for males. The low GSI values for the $\mathrm{Fr}$ samples indicate that the sampling in the Bay of Biscay was done at the end of the reproductive season. However, sexual differences in DM were observed also for spawning Fr individuals. Male hake, as described for cod, may present sexually dimorphic DM during and sometime after the termination of spawning (Nordeide et al. 2008). Non-spawning individuals could not be captured in French waters as the two cruises (sampling programmes) were restrained to the supposed reproductive period. Fortunately, in $\mathrm{Nw}$ waters both fish from mid-September until late November including spawning and non spawning individuals could be collected.

The drumming muscles of the male hake swimbladder clearly enlarge as the male becomes sexually mature. In female hake, on the other hand, there is no increase in the size of the DM with sexual maturity and no significant increase with increase in the size of the fish. Similarly, controlling for the influence of body size, Rowe and Hutchings (2004) found that male Atlantic cod have larger DM than females and that among males, DM increase in mass before spawning and decline thereafter. In haddock, which also belongs to the cod family (Gadidae), the sexually dimorphic drumming muscles of mature males increase to nearly twice their normal size during the spawning period (Templeman and Hodder 1958; Hawkins et al. 1967). Templeman and Hodder (1958) found no significant difference between the volumes of the DM of female haddock at different seasons. This sex-specific developmental pattern may reflect the important function of the drumming muscles, and thus of sound production, in the reproductive behaviour of haddock (Templeman and Hodder 1958). Both sexes of cod and haddock call during most of the year, whereas only males seem to call during the spawning period (Brawn 1961; Hawkins and Rasmussen 1978; Hawkins and Amorim 2000). Both male and female haddock were observed in tank to produce short sequences of repeated 'knocks' during agonistic encounters. In cod, grunts are produced during defensive and aggressive behaviour by both sexes when examined in aquarium tanks in the laboratory and in netting enclosures in the sea (Hawkins and Rasmussen 1978). During the spawning season, however, male fish produce sounds which vary in their characteristics as courtship proceeds (Hawkins and Amorim 2000). Sexual dimorphism and seasonal variation in sound-producing musculature have been documented for several other fishes, including weakfish (Connaughton and Taylor 1994), plainfin midshipman (Porichthys notatus) (Brantley and Bass 1994; Bass 1997) and Opsanus tau (Gray and Winn 1961). In some members of the family Sciaenidae only the males possess specially developed DM, e.g. the gray squeteague Cynoscion regalis (Fish 1954). For others, both sexes produce sound, as for the sea horse, Hippocampus brevirostris, in which both males and females make sounds most intense and most frequent during the breeding period (Dufossé 1874).

We suggest that mature male hake use their drumming muscles more often than either mature females or immatures of either sex, because these muscles in mature males are more highly vascularised (darker red) than those of mature females (light pink). As well, drumming muscle mass in males and females is similar prior to spawning, but during the spawning season it increases significantly in males. According to Lucio et al. (2000), first maturity is reached in Merluccius merluccius around $42 \mathrm{~cm}$ (both sexes 
combined). We could therefore expect that hake males and females do not have significant different DM until their first maturity.

\section{Conclusion}

This study showed for the first time the presence of drumming muscles in hake. During the spawning season only drumming muscles from male individuals are hypertrophied. Based on comparisons established with other gadoids we can thus suppose that sound production by adult males is more frequent during the spawning season than during the rest of the year. It is suggested that differences in size of the drumming muscles of male and female hake reflect changes in sound production with sex, sexual maturity, and season.

Acknowledgements Authors would like to specially thank fishermen for welcoming us on board to collect the biological material and Audrey Geffen for financial support (University of Bergen, Norway). Thanks to Ignacio Serrano for his help in dissecting fish. Finally thanks to Jon Egil Skjæraasen for his advices while initiating this study as well to Anne-Christine Utne Palm (University of Bergen, Norway).

Open Access This article is distributed under the terms of the Creative Commons Attribution Noncommercial License which permits any noncommercial use, distribution, and reproduction in any medium, provided the original author(s) and source are credited.

\section{References}

Alvarez P, Motos L, Uriarte A, Egaña J (2001) Spatial and temporal distribution of European hake, Merluccius merluccius (L.), eggs and larvae in relation to hydrographical conditions in the Bay of Biscay. Fish Res 50(1-2):111-128

Bass AH (1997) Comparative neurobiology of vocal behavior in teleost fishes. Mar Freshw Behav Physiol 29:47-63

Brantley RK, Bass AH (1994) Alternative male spawning tactics and acoustic-signals in the plainfin midshipman fish Porichthys notatus Girard (Teleostei, Batrachoididae). Ethology 96:213-232

Brawn VM (1961) Sound production by the cod (Gadus callarias L.). Behaviour 18:239-255

Casey J, Pereiro JA (1995) European hake (M. merluccius) in the North-east Atlantic. In: Alheit J, Pitcher TJ (eds) Hake: fisheries and markets. Chapman \& Hall, London, pp 125-147

Connaughton MA, Taylor MH (1994) Seasonal cycles in the sonic muscles of the weakfish, Cynoscion regalis. Fish Bull (Wash DC) 92:697-703

Delaroche FE (1809) Observations sur la vessie aérienne des poissons. Ann Mus Hist Nat Paris 14:245-298
Dufossé M (1874) Recherches sur les bruits et les sons expressifs que font entendre des poisons d'Europe. Ann Sci nat Zool 19(5):1-53, and 20(3):1-134

Fish MP (1954) The character and significance of sound production among fishes of the western North Atlantic. Bull Bing Ocean Coll 14(3):1-109

Gray GA, Winn HE (1961) Reproductive ecology and sound production of the toadfish, Opsanus tau. Ecology 42:274-282

Hagman N (1921) Studien über dis Schwimmblase einiger Gadiden und Macruriden 1. Gestalt des Organes und Befestigung desselben binnen Leibeshöhle. Carl Bloms, Lund, p 124

Hawkins AD, Amorim MCP (2000) Spawning sounds of the male haddock, Melanogrammus aeglefinus. Environ Biol Fish 59:29-41

Hawkins AD, Chapman CJ (1966) Underwater sounds of the haddock, Melanogrammus aeglefinus. J Mar Biol Assoc U K 46:241-247

Hawkins AD, Myrberg AA Jr (1983) Hearing and sound communication underwater. In: Lewis B (ed) Bioacoustics, a comparative approach. Academic, London, pp 347-405

Hawkins AD, Rasmussen KJ (1978) The calls of gadoid fish. J Mar Biol Assoc U K 58:891-911

Hawkins AD, Chapman CJ, Symonds DJ (1967) Spawning of haddock in captivity. Nature (Lond) 215:923-925

Jones FRH, Marshall NB (1953) The structure and functions of the teleostean swimbladder. Biol Rev 28:16-83

Ladich F, Myrberg AA Jr (2006) Agonistic behavior and acoustic communication. In: Ladich F, Collin SP, Moller P, Kapoor BG (eds) Communication in fishes, vol. 1. Science Publishers, Enfield, pp 121-148

Lucio P, Murua H, Santurtún M (2000) Growth and reproduction of hake (Merluccius merluccius) in the Bay of Biscay during the period 1996-1997. Ozeanografika 3:325-354

Myrberg AA Jr, Lugli M (2006) Reproductive behavior and acoustical interactions. In: Ladich F, Collin SP, Moller P, Kapoor BG (eds) Communication in fishes, vol. 1. Science Publishers, Enfield, pp 149-176

Nordeide JT, Solberg C, Willumsen L, Amble S (2008) Seasonal variation and condition-dependence of the drumming muscle of cod, Gadus morhua L.?-An experimental approach. J Exp Mar Biol Ecol 363:66-74

Olivar MP, Quílez G, Emelianov M (2003) Spatial and temporal distribution and abundance of European hake, Merluccius merluccius, eggs and larvae in the Catalan coast (NW Mediterranean). Fish Res 60(2-3):321-331

Rountree RA, Goudey C, Hawkins T (2003) In: Rountree RA, Goudey C, Hawkins T (eds) Listening to fish: proceedings of the international workshop on the applications of passive acoustics to fisheries, April 8-10, 2002, MIT Sea Grant Technical Report, Dedham, MA, pp 4-10

Rowe S, Hutchings JA (2004) The function of sound production by Atlantic cod as inferred from patterns of variation in drumming muscle mass. Can J Zool 82:1391-1398

Sørensen W (1884) Om Lydorganer hos Fiske. En Physiologisk og Comparativ-anatomisk Undersøgelse. Copenhagen, Thaning pp 245

Templeman W, Hodder VM (1958) Variation with fish length, sex, stage of sexual maturity and season, in the appearance and volume of the drumming muscles of the swimbladder in the haddock, Melanogrammus aeglefinus L. J Fish Res Board Can 15:355-390 